\title{
Elemental composition of fluid in the human Fallopian tube
}

\author{
R. M. Borland, J. D. Biggers, C. P. Lechene* and M. L. Taymor $\dagger$ \\ Departments of Physiology and $†$ Obstetrics and Gynecology, and \\ *National Biotechnology Resource in Electron Probe Microanalysis, \\ Laboratory of Human Reproduction and Reproductive Biology, Harvard Medical School, \\ 45 Shattuck Street, Boston, Massachusetts 02115, U.S.A.
}

\begin{abstract}
Summary. Relatively undisturbed samples of human oviduct fluid were obtained by aspiration into a Silastic catheter inserted through the fimbriated end of the oviduct during surgical laparotomy. The concentrations of $\mathrm{Na}, \mathrm{Cl}, \mathrm{K}, \mathrm{Ca}, \mathrm{Mg}, \mathrm{S}$ and $\mathrm{P}$ were determined in picolitre aliquots of this fluid using X-ray spectrometry by electron probe excitation. Human tubal fluid has a unique elemental composition characterized by high concentrations of $\mathrm{K}$ and $\mathrm{Cl}$, but low concentrations of $\mathrm{Ca}$, relative to the range of normal human serum values. $\mathrm{Na}$ and $\mathrm{Mg}$ concentrations in oviduct fluid are similar to serum levels.
\end{abstract}

\section{Introduction}

The oviduct provides the milieu for several critically important reproductive events, including transport of ova and spermatozoa, conditioning of the gametes, fertilization, and preimplantation embryonic development. Extensive work on the composition of oviduct fluid in a number of species has involved the use of double-ligature or cannulation techniques, and collection of fluid for long periods (for review, see Johnson \& Foley, 1974). Up to the present, only two chemical analyses of human tubal fluid have been reported (Lippes, Enders, Pragay \& Bartholomew, 1972; David, Serr \& Czernobilsky, 1973). Both studies indicated that human oviduct fluid contains higher concentrations of chloride and potassium than does human serum. Roblero, Biggers \& Lechene (1976) and Borland, Hazra, Biggers \& Lechene (1977) have reported techniques for obtaining relatively undisturbed samples of oviduct fluid from the mouse and using electron probe excitation to analyse simultaneously in each sample seven different elements. Modifications of these techniques have now been used to analyse human tubal fluid from patients undergoing laparotomy.

\section{Materials and Methods}

Patients undergoing hysterectomy and bilateral salpingoophorectomy for menometrorrhagia provided the tubal fluid for this study (Table 1). The patients varied in age from 30 to 48 years and were premenopausal, except for patient R.M., who was perimenopausal. The patients were in various stages of their menstrual cycles, as estimated by the number of days since their last menstrual cycle and the endometrial histology. Histological sections of the oviducts indicated that no gross pathological processes disturbed normal oviduct morphology. Informed consent was obtained before surgery. After the abdomen was opened and just before the start of the hysterectomy, a Silastic (Dow Corning, Midland, Michigan) catheter containing sterile mineral 
oil was then threaded down the fimbriated end of each Fallopian tube to a depth of $2 \cdot 5-5 \cdot 0 \mathrm{~cm}$. A silk ligature was then placed around the oviduct and catheter near the fimbriated end to provide a tight seal. A $10 \mathrm{ml}$ syringe with a blunt needle was attached to the catheter and negative pressure was exerted for $1 \mathrm{~min}$. The catheter was then carefully withdrawn and its contents expelled into a Petri dish of mineral oil. Care was required to avoid contamination of tubal fluid with blood.

Table 1. Historical information on patients providing oviduct fluid for the present study

\begin{tabular}{|c|c|c|c|c|c|c|c|}
\hline Name & $\begin{array}{c}\text { Age } \\
\text { (years) }\end{array}$ & $\begin{array}{l}\text { Time from } \\
\text { last } \\
\text { menstrual } \\
\text { period }\end{array}$ & $\begin{array}{l}\text { Obstetrical } \\
\text { history* }\end{array}$ & $\begin{array}{l}\text { Endometrial } \\
\text { histology }\end{array}$ & $\begin{array}{l}\text { Oviduct } \\
\text { histology }\end{array}$ & $\begin{array}{c}\text { Post-operative } \\
\text { diagnosis }\end{array}$ & Comments \\
\hline E.H. & 42 & 22 days & G5P3A2 & - & $\begin{array}{l}\text { No } \\
\text { pathology }\end{array}$ & $\begin{array}{l}\text { Uterine } \\
\text { leiomyomata }\end{array}$ & - \\
\hline R.M. & 48 & 1 year & G3P1A2 & $\begin{array}{l}\text { Inactive } \\
\text { endometrium }\end{array}$ & $\begin{array}{l}\text { No } \\
\text { pathology }\end{array}$ & $\begin{array}{l}\text { Uterine } \\
\quad \text { leiomyomata }\end{array}$ & $\begin{array}{l}\text { Patient } \\
\text { perimenopausal }\end{array}$ \\
\hline G.K. & 30 & 22 days & G2P0 & - & $\begin{array}{l}\text { Mild } \\
\text { chronic } \\
\text { salpingitis }\end{array}$ & $\begin{array}{l}\text { Chronic } \\
\text { cervicitis } \\
\text { with dysplasia }\end{array}$ & - \\
\hline P.T. & 32 & 16 days & G2PlA1 & $\begin{array}{l}\text { Early } \\
\text { secretory } \\
\text { changes }\end{array}$ & $\begin{array}{l}\text { No } \\
\text { pathology }\end{array}$ & $\begin{array}{l}\text { Haemorrhagic } \\
\text { corpus } \\
\text { luteum cyst }\end{array}$ & - \\
\hline M.O. & 43 & 22 days & G4P4 & $\begin{array}{l}\text { Proliferative } \\
\text { endometrium }\end{array}$ & $\begin{array}{l}\text { No } \\
\text { pathology }\end{array}$ & $\begin{array}{l}\text { Uterine } \\
\text { leiomyomata }\end{array}$ & $\begin{array}{l}\text { On birth } \\
\text { control pills }\end{array}$ \\
\hline L.S. & 43 & - & G4P2A2 & $\begin{array}{l}\text { Mid- } \\
\text { proliferative } \\
\text { endometrium }\end{array}$ & $\begin{array}{l}\text { Mild } \\
\text { chronic } \\
\text { salpingitis }\end{array}$ & $\begin{array}{l}\text { Uterine } \\
\text { leiomyomata }\end{array}$ & $\begin{array}{l}\text { Menometrorrhagi } \\
\text { for } 3 \text { years }\end{array}$ \\
\hline S.L. & 36 & 26 days & GOPO & $\begin{array}{l}\text { Late } \\
\text { secretory } \\
\text { endometrium }\end{array}$ & $\begin{array}{l}\text { Hydatids } \\
\text { of } \\
\text { Morgagni }\end{array}$ & $\begin{array}{l}\text { Uterine } \\
\text { adenomyosis } \\
\text { and } \\
\text { leiomyomata }\end{array}$ & - \\
\hline
\end{tabular}

* $\mathrm{G}=$ gravidity $; \mathrm{P}=$ parity $; \mathrm{A}=$ abortion .

An aliquot of each sample was drawn into a siliconized oil-filled micropuncture pipette. Additional mineral oil was taken into the pipette and the tip sealed by heat without disturbance to the sample. The pipette was then centrifuged for $15 \mathrm{~min}$ at $1470 \mathrm{~g}$ in a model CL International Clinical Centrifuge to separate any cells from the light yellow supernatant fluid. Samples with any blood contamination were not included in the study.

Sample preparation and electron probe microanalysis were by the techniques described by Lechene (1974), Lechene \& Warner (1977) and Borland et al. (1977). The samples were first diluted $1: 1$ or $1: 2$ with distilled water. The samples and a series of standard solutions were placed on the surface of a beryllium support covered with mineral oil with calibrated volumetric pipettes $(35-80 \mathrm{pl})$. The oil on the beryllium block was removed with an $m$-xylene wash and the sample on the block was freeze-dried under vacuum. The analyses were performed on an automated Cameca MS/46 microprobe. X-ray emissions from $\mathrm{Na}$ and $\mathrm{Mg}$ were analysed using potassium acid phthalate diffracting crystals; $\mathrm{P}, \mathrm{Cl}, \mathrm{K}$ and $\mathrm{Ca}$ required the use of pentaerythritol diffracting crystals. The concentrations of the elements in the unknown samples were determined with respect to the counts obtained from identical volumes of 5 standard solutions each of which contained known amounts of the 7 elements being studied. The electron probe measures the total content of all 7 elements in each sample and therefore the concentrations of $\mathrm{Ca}$ and $\mathrm{Mg}$ included the bound and unbound forms of these elements, and those of $S$ and $\mathbf{P}$ represented the organic and inorganic forms. The electron probe has been shown to analyse reliably elements in fluid volumes as small as $10 \mathrm{pl}$ provided the elemental concentrations are greater than $0.3 \mathrm{~mm}$ (Lechene \& Warner, 1977).

Preoperative serum electrolyte concentrations were obtained from the chemistry laboratory of the Peter Bent Brigham Hospital, Boston, where the surgery was performed. Serum $\mathrm{Na}$ and $\mathrm{K}$ 
were analysed by flame photometry, whereas serum $\mathrm{Cl}$ and $\mathrm{Ca}$ were analysed by titration and fluorometry, respectively. The ranges of normal serum electrolyte concentrations at the Peter Bent Brigham Hospital are shown in Table 3. Surgical specimens were examined by the hospital pathology department. The endometrial and tubal histologies and post-operative diagnoses are shown in Table 1.

\section{Results and Discussion}

The mean concentrations of $\mathrm{Na}, \mathrm{Cl}, \mathrm{K}, \mathrm{Ca}, \mathrm{Mg}, \mathrm{S}$ and $\mathrm{P}$ in human tubal fluids from seven patients are shown in Table 2. The ionic composition of the fluid was characterized by high concentrations of $\mathrm{K}$ and $\mathrm{Cl}$, but low concentrations of $\mathrm{Ca}$, relative to corresponding serum levels.

Table 2. Concentration (mM) of $\mathrm{Na}, \mathrm{Cl}, \mathrm{K}, \mathrm{Ca}, \mathrm{Mg}, \mathrm{S}$ and $\mathbf{P}$ in human oviduct fluid and human serum

\begin{tabular}{llllrllll}
\hline Name & Fluid & $\mathrm{Na}$ & $\mathrm{Cl}$ & $\mathrm{K}$ & $\mathrm{Ca}$ & $\mathrm{Mg}$ & $\mathrm{S}$ & $\mathrm{P}$ \\
\hline E.H. & Tubal & 127.4 & 131.4 & 15.6 & 1.66 & 0.34 & 5.50 & 5.84 \\
& Serum & 145 & 111 & 3.9 & 2.62 & - & - & - \\
R.M. & Tubal & 104.2 & 122.2 & 15.3 & 0.85 & 1.32 & 18.44 & 7.30 \\
G.K. & Tubal & 140.7 & 161.7 & 27.2 & 0.15 & 1.71 & 5.73 & $\mathbf{9 . 5 4}$ \\
& Serum & 142 & - & 4.3 & - & - & - & - \\
P.T. & Tubal & 128.4 & 131.4 & 21.5 & 0.72 & 2.64 & 13.92 & 8.73 \\
M.O. & Tubal & 144.7 & 143.1 & 29.7 & 1.94 & 1.24 & 10.08 & 9.08 \\
& Serum & 131 & 95 & 4.1 & - & - & - & - \\
L.S. & Tubal & 134.4 & 124.3 & 15.4 & 1.67 & 1.29 & 16.06 & 9.28 \\
& Serum & 140 & 105 & 4.9 & - & - & - & - \\
S.L. & Tubal & 135.0 & 107.5 & 23.5 & 0.95 & 1.37 & 16.35 & 11.07 \\
& Serum & 145 & 113 & 3.8 & 2.52 & - & - & - \\
\hline
\end{tabular}

The mean concentrations of the 7 elements in the oviduct fluids of our study are compared to previous elemental analyses of human tubal fiuid (Table 3). Lippes et al. (1972) and David et al. (1973) also reported that $\mathrm{K}$ and $\mathrm{Cl}$ concentrations in oviduct fluid are consistently higher than in serum. The former investigators also noted that $\mathrm{Ca}$ concentrations in oviduct fluid are at the lower end of the normal range of the corresponding serum levels. The results of our own study show similar trends, but also indicate much higher concentrations of $\mathrm{K}$ in human oviduct fluid than previously reported. Human tubal fluid contains 4-5-fold higher concentrations of $\mathrm{K}$ than does human serum. The $\mathrm{Ca}$ concentration in oviduct fluid is less than half the serum $\mathrm{Ca}$ levels (Table 3), perhaps reflecting lower concentrations of protein in tubal fluid than in serum (David et al., 1973) which could maintain $\mathrm{Ca}$ in a protein-bound form. The $\mathrm{Mg}$ concentration was not

Table 3. Mean ( \pm s.e.m.) concentrations of various elements in the fluid of human oviducts

\begin{tabular}{|c|c|c|c|c|c|c|}
\hline \multirow[b]{3}{*}{ Element } & \multirow{3}{*}{$\begin{array}{l}\text { Hospital } \\
\text { normal ranges } \\
\text { for human } \\
\text { serum }\end{array}$} & \multirow{3}{*}{$\begin{array}{c}\text { Borland et al. } \\
(1979) \\
(\mathbf{N}=7)\end{array}$} & \multicolumn{4}{|c|}{ Tubal fluid (mм) } \\
\hline & & & \multicolumn{2}{|c|}{$\begin{array}{l}\text { Lippes et al. (1972) } \\
\qquad(\mathrm{N}=16)\end{array}$} & \multicolumn{2}{|c|}{ David et al. (1973) } \\
\hline & & & Pre-ovulatory & Post-ovulatory & $\begin{array}{l}\text { Pre-ovulatory } \\
(\mathrm{N}=13)\end{array}$ & $\begin{array}{l}\text { Post-ovulatory } \\
(N=11)\end{array}$ \\
\hline $\mathrm{Na}$ & $139-147$ & $130 \pm 5$ & $140 \pm 3$ & $139 \pm 2$ & $142 \pm 4$ & $148 \pm 5$ \\
\hline $\mathrm{Cl}$ & $102-113$ & $132 \pm 6$ & $119 \pm 4$ & $117+3$ & $127+20$ & $112+11$ \\
\hline K & $3 \cdot 6-5 \cdot 0$ & $21.2 \pm 0.24$ & $9.9 \pm 1.8$ & $7.7 \pm 0.9$ & $6.7 \pm 1.3$ & $6.7 \pm 0.5$ \\
\hline $\mathrm{Ca}$ & $2 \cdot 27-2 \cdot 72$ & $1.13 \pm 0.24$ & $1.89 \pm 0.52$ & $2.37 \pm 0.27$ & $=$ & 二- \\
\hline $\mathrm{Mg}$ & $0.55-1.57$ & $1.42 \pm 0.26$ & $0.53-0.69$ & 二 & - & - \\
\hline $\mathrm{S}$ & - & $12.3 \pm 1.9$ & - & - & - & 一 \\
\hline $\mathrm{P}$ & - & $8.69 \pm 0.64$ & - & - & - & - \\
\hline
\end{tabular}


significantly different from the normal range of serum $\mathrm{Mg}$ levels. The reason for the discrepancy in $\mathrm{K}$ concentrations in Table 3 is not known, but may be related to differences in patient selection and fluid sampling techniques. There is no reason to suspect artefactually high $\mathrm{K}$ measurements because of the use of electron probe microanalysis. In our hands, measurements of $\mathrm{K}$ concentrations in biological fluids with the electron probe are identical to results with flame photometry.

The present values for human oviduct fluid are similar to those obtained for fluid from the isthmic and ampullary regions of the mouse oviduct under highly controlled laboratory conditions; i.e. high concentrations of $\mathrm{K}$ and $\mathrm{Cl}$, but low concentrations of $\mathrm{Ca}$ (Roblero et al., 1976; Borland et al., 1977). The importance of this ionic composition for fertilization and preimplantation embryonic development in women and mice is not yet known. The human embryo normally enters the uterus at the 8- or 16-cell stage. Human oocytes that have been fertilized in vitro cleave regularly, albeit more slowly than in vivo, and eventually form blastocysts in culture medium that is ionically dissimilar to human tubal fluid (Steptoe \& Edwards, 1976, 1978). Further studies are needed to determine the importance of the ionic composition of the oviduct fluid for normal human preimplantation development.

Supported by National Institute of Health Grant HD 06916-03, and National Institute of Health Centers Grant 1-P01-HD 066-15-04.

\section{References}

Borland, R.M., Hazra, S., Biggers, J.D. \& Lechene, C.P. (1977) The elemental composition of the environments of the gametes and preimplantation embryo during the initiation of pregnancy. Biol. Reprod. 16, 147-157.

David, A., Serr, D.M. \& Czernobilsky, B. (1973) Chemical composition of human oviduct fluid. Fert. Steril. 24, 435-439.

Johnson, A.D. \& Foley, C.W. (1974) The Oviduct and its Function. Academic Press, New York.

Lechene, C.P. (1974) Electron probe microanalysis of picoliter liquid samples. In Microprobe Analysis as Applied to Cells and Tissues, pp. 351-368. Eds T. Hall, R. Echlin \& R. Kaufman. Academic Press, New York.
Lechene, C.P. \& Warner, R.R. (1977) Ultramicroanalysis: $\mathrm{X}$-ray spectrometry by electron probe excitation. Ann. Rev. Biophys. Bioeng. 6, 57-85.

Lippes, J., Enders, R.G., Pragay, D.A. \& Bartholomew, W.R. (1972) The collection and analysis of human Fallopian tubal fluid. Contraception 5, 85-95.

Roblero, L., Biggers, J.D. \& Lechene, C.P. (1976) Electron probe microanalysis of the elemental microenvironment of oviducal cleavage stages of the mouse. J. Reprod. Fert. 46, 431-434.

Steptoe, P.C. \& Edwards, R.G. (1976) Reimplantation of a human embryo with subsequent tubal pregnancy. Lancet i, 880-882.

Steptoe, P.C. \& Edwards, R.G. (1978) Birth after the reimplantation of a human embryo. Lancet ii, 366 .

Received 14 September 1979 